\title{
Pengaruh Buah Pepaya Terhadap Nafsu Makan Anak 2-5
}

\author{
Nancy Olii, Rabia Zakaria, Bun Yamin Badjuka \\ Jurusan Kebidanan Politeknik Kesehatan Kemenkes Gorontalo \\ oliinancy7@gmail.com
}

\begin{abstract}
ABSTRAK
Latar Belakang: Data GHI (Global Hunger Index) yang menyatakan bahwa Indonesia tergolong negara yang termasuk kategori serius atau berada dibawah level mengkawatirkan dalam jumlah penderita gizi buruk. Jumlah penderita gizi buruk seperti gunung es, kasus yang muncul kepermukaan sedikit. Buah pepaya mengandung enzim papain. Enzim ini sangat aktif dan memiliki kemampun mempercepat proses pencernaan protein. Papain dapat membantu mewujudkan proses pencernaan makanan yang lebih baik, dengan cara ini sistem kekebalan tubuh dapat ditingkatkan. Buah pepaya juga kaya akan vitamin B kompleks yang dapat meningkatkan laju reaksi metabolisme tubuh, merangsang hipotalamus untuk meningkatkan nafsu makan dan menyokong pertumbuhan.

Tujuan: untuk mengetahui pengaruh buah pepaya terhadap nafsu makan anak berumur 2-5 Tahun di PAUD Moheingo Kecamatan Tilango Kabupaten Gorontalo..

Metode: Jenis Penelitian yaitu pre experimen yang bersifat One Group Pre Test-Post Test Design. Populasi adalah balita yang berada di PAUD Moheingo Kecamatan Tilango Kabupaten Gorontalo, dengan sampel 28 responden..

Hasil: Setelah dilakukan pemberian buah pepaya terdapat perbedaan mean sebesar 0.61 dengan standar deviasi 0.497. Hasil analisis statistik menunjukkan pemberian buah pepaya berpengaruh terhadap peningkatan nafsu makan pada anak 2-5 tahun di wilayah kerja Puskesmas Tilango Kabupaten Gorontalo.
\end{abstract}

Kesimpulan: Buah Pepaya yang diberikan 100 gr setiap hari selama 14 hari dapat dijadikan salah satu alternatif dalam meningkatkan nafsu makan anak 2-5 tahun.

\section{Kata Kunci: Pepaya, Nafsu Makan, Balita}

\begin{abstract}
Background: GHI (Global Hunger Index) data that states that Indonesia belongs to a country that belongs to a serious category or below the level of concern in the number of people with malnutrition. The number of people with malnutrition such as icebergs, cases that seem to surface are small. Papaya fruit contains papain enzymes. This enzyme is very active and has the maturity to speed up the digestive process of proteins. Papain can help realize a better digestive process of food, in this way the immune system can be improved. Papaya fruit is also rich in B complex vitamins that can increase the body's metabolic reaction rate, stimulate the hypothalamus to increase appetite and support growth.

Purpose: to know the effect of papaya fruit on the appetite of children aged 2-5 years in PAUD Moheingo District Tilango Gorontalo Regency

Method: The type of research is pre experiment which is One Group Pretest-Posttest Design. The population is toddlers who are in PAUD Moheingo District of Tilango Gorontalo Regency, with a sample of 28 respondents..

Result: After the administration of papaya fruit there is a mean difference of 0.61 with a standard deviation of 0.497 . The results of statistical analysis showed papaya fruit administration had an effect on the increase in appetite in children 2-5 years old in the working area of Puskesmas Tilango Kabupaten Gorontalo.
\end{abstract}


Conclusion: Papaya fruit given 100 gr daily for 14 days can be used as an alternative in increasing the appetite of children 2-5 years.

\section{Keywords: Papaya, Appetite, Toddler}

\section{PENDAHULUAN}

Setiap tahun Balita di Indonesia yang menderita gizi buruk dan ini merata tersebar di seluruh Indonesia. Prevalensi gizi buruk terus mengalami penurunan dari 9,7\% di tahun 2005 menjadi 4,9\% di tahun 2010 dan diharapkan ditahun 2015, prevalensi gizi buruk dapat turun menjadi $3,6 \%$. Prevalensi anak balita gizi kurang dan buruk turun $0,5 \%$ dari $18,4 \%$ pada 2007 menjadi 17,9\% pada 2010. Berbeda dengan GHI (Global Hunger Index) yang menyatakan bahwa Indonesia tergolong negara yang termasuk kategori serius atau berada dibawah level mengkawatirkan dalam jumlah penderita gizi buruk. Jumlah penderita gizi buruk seperti gunung es, kasus yang muncul kepermukaan sedikit ${ }^{(1)}$.

Masa Balita (golden period) merupakan masa emas yang sangat peka terhadap lingkungan dan masa ini berlansung sangat pendek serta tidak dapat diulang lagi. Pada masa kritis ini, otak balita lebih plastis. Plastisitas otak pada balita mempunyai sisi positif dan negative. Sisi positifnya, otak balita lebih terbuka untuk proses pembelajaran dan pengkayaan. Sisi negatifnya, otak balita lebih peka terhadap lingkungan yang tidak mendukung seperti masukan gizi yang tidak adekuat $^{(2)(3)(4)}$.

Asupan gizi yang tidak adekuat disebabkan pada anak balita terjadi kesulitan makan berupa berkurangnya nafsu makan yang berkaitan dengan makin meningkatnya interaksi dengan lingkungan. Balita lebih mudah terkena penyakit terutama penyakit infeksi baik yang akut maupun yang menahun, infeksi cacing dan dalam waktu yang lama bisa menyebabkan gizi kurang atau gizi buruk (5) (6) (7).

Anak yang tidak menyukai makanan tertentu misalnya buah atau sayur akan terjadi defisiensi vitamin A. Bila hanya mau minum susu saja akan terjadi anemi defisiensi besi. Bila kekurangan kalori dan protein akan terjadi kekurangan energi protein $^{(1)}$ (7) (3) (8).

Banyak orang tua yang kesulitan dalam menghadapi masalah kurangnya nafsu makan pada anak. Obat-obatan selalu saja menjadi pilihan utama untuk kondisi ini. Obat penambah nafsu makan dalam jangka waktu yang lama menyebabkan penyakit kronis yang lain. Pilihan lain yang dapat diambil adalah dengan mengonsumsi multivitamin non farmakologis. Multivitamin berupa buah - buahan yang memiliki nilai gizi yang cukup tinggi, rasanya manis, dengan harga murah dan mudah didapatkan adalah Carica Pepaya ${ }^{(9)}$ (1) (10).

Menurut Villegas, ahli pepaya dari Institute of Plant Breeding, University of the Philippines at Los Banos (1992), buah pepaya mengandung enzim papain. Enzim ini sangat aktif dan memiliki kemampuan mempercepat proses pencernaan protein. Papain dapat membantu mewujudkan proses pencernaan makanan yang lebih baik (9) (11) dengan cara ini sistem kekebalan tubuh dapat ditingkatkan. Buah pepaya juga kaya akan vitamin B kompleks yang dapat meningkatkan laju reaksi metabolisme tubuh, merangsang hipotalamus untuk 
meningkatkan nafsu makan dan menyokong pertumbuhan ${ }^{(1)(11)(10)}$.

Berdasarkan data yang didapatkan dari Dinas Kesehatan Provinsi Gorontalo tahun 2017 di Provinsi Gorontalo dilakukan Pemantauan Status Gizi (PSG) tercatat wilayah kasus gizi kurang terdapat di Kabupaten Gorontalo 19,8\% Kabupaten Boalemo 30,8\%, dan Kabupaten Bone Bolango 16,4\%.

Pada tahun 2017 kasus gizi kurang yang terdeteksi di 21 puskesmas di Kabupaten Gorontalo jumlah penderita balita gizi kurang sebanyak 861 jiwa. Data Puskesmas Tilango berjumlah 188 jiwa. Tujuan penelitian menganalisis pengaruh pemberian buah pepaya terhadap nafsu makan anak 2-5 tahun di Wilayah Kerja Puskesmas Tilango Kabupaten Gorontalo.

\section{METODE}

Penelitian ini menggunakan pendekatan Pre Eksperimen yang bersifat, One Group Pre Test-Post Test Design. Penelitian dilaksanakan pada bulan JanuariFebruari 2018 dengan populasi berjumlah 75 orang anak berumur 2-5 tahun di PAUD Hemoingo Desa Tabumela wilayah kerja Puskesmas Tilango Kabupaten Gorontalo, dengan sampel 28 responden dan teknik Purposive Sampling. Observasi dilakukan melalui pengukuran frekuensi makan frekuensi makan dilakukan dalam waktu 14 hari. buah pepaya diberikan.

\section{HASIL}

\section{Data Umum Responden}

Tabel 1 Distribusi frekuensi berdasarkan jenis kelamin, usia, pemberian buah papaya, berat badan dan peningkatan berat badan pada anak 2-5 tahun di wilayah kerja Puskesmas Tilango Kabupaten Gorontalo

\begin{tabular}{lcc}
\hline \multirow{2}{*}{ Variabel } & \multicolumn{2}{c}{ Jumlah } \\
\cline { 2 - 3 } & $\mathrm{f}$ & $\%$ \\
\hline Jenis Kelamin : & 13 & 46.4 \\
$\quad$ Perempuan & 15 & 53.6 \\
$\quad$ Laki-laki & & \\
Usia & 9 & 32.1 \\
$\quad$ 2-3 Tahun & 19 & 67.9 \\
$\quad$ 4-5 Tahun & & \\
Pemberian Buah Pepaya & 28 & 100,0 \\
$\quad$ Dilakukan & 0 & 0 \\
$\quad$ Tidak Dilakukan & & \\
Berat Badan & 17 & 60.7 \\
$\quad$ Sedang (9,9 kg-13,8 kg) & 11 & 39.3 \\
$\quad$ Baik (12,3 kg-17,7 kg) & 11 & \\
Berat Badan & & 0 \\
$\quad$ Tidak meningkat & 0 & 0 \\
$\quad$ Meningkat & 28 & 100.0 \\
\hline
\end{tabular}

Berdasarkan tabel 1 menunjukkan jenis kelamin responden penelitian ini laki- laki lebih banyak dibanding perempuan. Berdasarkan umur 2-3 tahun lebih kecil 
dibanding 4-5 tahun, Berdasarkan table 3 dilakukan pemberian buah pepaya terhadap 28 responden. Keberhasilan perlakuan pemberian buah pepaya dalam menaikkan berat badan. 28 responden sebelum pemberian buah pepaya yang memiliki berat badan kategori sedang ada 17 responden (60.7\%) dan dalam kategori baik sebanyak 11 responden $(39.3 \%)$.

2. Analisis Bivaria

Tabel 2. Pengaruh Pemberian Buah Pepaya terhadap Nafsu Makan Anak 2-5 Tahun Di Wilayah Kerja Puskesmas Tilango Kabupaten Gorontalo

\begin{tabular}{cccccc}
\hline Berat Badan & N & Mean & SD & Z & $\begin{array}{c}\text { Sig } \\
\text { (Wilcoxon) }\end{array}$ \\
\hline Berat badan sebelum & 28 & 1,39 & 0,497 & 3.317 & 0.001 \\
Berat badan Sesudah & 28 & 2.00 & 0,000 & & \\
\hline
\end{tabular}

Berdasarkan data pada tabel di atas menunjukkan bahwa rata-rata berat badan dan frekuensi makan pada anak 2-5 tahun di PAUD Moheingo Wilayah Kerja Puskesmas Tilango Kabupaten Gorontalo sebelum dilakukan pemberian buah pepaya dan Setelah dilakukan pemberian buah pepaya terdapat perbedaan mean sebesar 0.61 dengan standar deviasi 0.497. dengan 000. hasil analisis statistik menunjukkan pemberian buah pepaya berpengaruh terhadap peningkatan nafsu makan pada anak 2-5 tahun di wilayah kerja Puskesmas Tilango Kabupaten Gorontalo.

\section{PEMBAHASAN}

Hasil penelitian menunjukkan bahwa pemberian buah pepaya berpengaruh terhadap peningkatan nafsu makan pada anak 2-5 tahun di wilayah kerja Puskesmas Tilango Kabupaten Gorontalo. Hasil penelitian ini didukung oleh penelitian Fajria(2013) yang menunjukkan semua responden mengalami peningkatan berat badan setelah mengkonsumsi 1 potong pepaya dengan berat $100 \mathrm{gr}$ perhari selama 1 bulan ${ }^{(1)}$.

Buah pepaya dapat mempengaruhi berat badan dikarenakan buah pepaya dapat mencegah terjadinya gangguan pencernaan pada organ lambung anak. Buah pepaya dapat meningkatkan nafsu makan anak dan kecepatan dalam penyerapan zat gizi. Kecepatan penyerapan zat gizi ini dipengaruhi oleh daya cerna, komposisi zat gizi, keadaan normal membran mukosa halus, hormon dan masukan vitamin yang adekuat ${ }^{(10)}$. Vitamin yang ada dalam buah pepaya merupakan senyawa organik tertentu yang diperlukan dalam jumlah kecil tetapi esensial untuk reaksi metabolisme dalam sel dan penting untuk melansungkan pertumbuhan normal dan memelihara kesehatan, oleh karena itu tubuh harus memperoleh vitamin dari makanan untuk mengatur metabolisme, mengubah lemak dan karbohidrat menjadi energi dan ikut membantu pembentukan tulang dan jaringan. Kandungan vitamin dan mineral dalam buah pepaya akan memulihkan nafsu makan anak, memperkuat daya tahan tubuh dan memulihkan kondisi sakit pada anak. Pepaya merupakan buah yang memiliki nilai gizi yang cukup tinggi, rasanya manis, dengan harga murah dan mudah didapat ${ }^{(1)}$. 
Seorang ibu harus mengetahui berbagai hal yang terkait dengan perannya dalam memilih menu dan jenis makanan yang akan diberikan pada anak. Ibu perlu mengetahui kandungan gizi pada makanan, jadwal makanan, cara mempersiapkan, cara menyajikan serta dalam mempersiapkan perlengkapan makannya ${ }^{(6),(12)}$. Seorang ibu harus mampu melatih makan pada anaknya dan sanggup mengantisipasi sewaktu anak susah makan ${ }^{(7),(13),(6)}$. Makanan berperan penting dalam pertumbuhan fisik dan kecerdasan anak. Pola makan yang baik dan teratur perlu diperkenalkan sejak dini. Penting sekali membina dan mengembangkan keterampilan makan pada anak yang dimulai sejak dini. Kebutuhan bahan makanan perlu diatur, sehingga bayi mendapatkan asupan gizi yang diperlukan secara utuh sesuai dengan usia dan kebutuhannya ${ }^{(5),(13),(14) .}$

Orangtua yang selalu menyediakan camilan atau memberikan jajanan pada anak, akan mengurangi minat anak untuk makan, sebab, ketika anak sudah dibiasakan untuk jajan, maka nafsu makannya terhadap makanan pokok akan menurun karena perutnya telah terisi dengan jajanan. Selain itu, sajian camilan dengan beragam bentuk, rasa dan warna akan cenderung membuat anak lebih tertarik menyantap camilan dibandingkan dengan nasi dan lauk pauk (5),(7),(13), untuk itu sebaiknya kontrol jumlah camilan yang diberikan pada anak agar nafsu makannya tetap berselera terhadap makanan pokok yang disajikan.

Anak yang mengalami kesulitan makan yang berlangsung lama akan berdampak pada kesehatan dan tumbuh kembang anak. Gejala yang timbul tergantung dari jenis dan jumlah zat gizi yang kurang. Anak yang tidak menyukai makanan tertentu misalnya buah atau sayur akan terjadi defisiensi vitamin A (4),(3). Perlunya penjelasan dari orang tua tentang manfaat makanan yang harus dimakan sehingga mengurangi rasa tidak enak dari makanan. Pada usia balita anak perlu dilakukan pelatihan dan pembinaan khusus perkembangan keterampilan makan secara optimal agar masalah/gangguan makan tidak muncul dikemudian hari. Stimulasi anak untuk aktif sangat diperlukan agar timbul rasa lapar ${ }^{(12),(15)}$.

Beberapa hal yang perlu diperhatikan dalam mengatasi dan menghadapi perilaku anak yang sulit makan yaitu ciptakan Suasana makan yang nyaman sehingga nafsu makan anak bertambah dan beri pengertian mengenai pentingnya makanan.orang tua tidak dianjurkan untuk memaksa anak untuk mengkonsumsi buah dan sayur. Orang tua yang memaksa anak untuk mengkonsumsi buah dan sayur dan akibatnya, anak akan bersikap dengan keras untuk menolak mengkonsumsi buah dan sayur dan memberontak ketika akan diberikan buah dan sayur (12),(7). Langkah yang perlu dilakukan orang tua dalam menyajikan buah dan sayur yaitu dengan beberapa desain atau tampilan yang menarik perhatian anak, agar mau makan buah dan sayur yang disiapkan sehingga membuat anak tertarik untuk memakannya (12),(15),(11).

\section{KESIMPULAN}

Berdasarkan hasil penelitian dan pembahasan dapat di simpulkan bahwa ada pengaruh pemberian buah pepaya terhadap nafsu makan anak 2-5 tahun di wilayah kerja Puskesmas Tilango kabupaten Gorontalo. 


\section{DAFTAR PUSTAKA}

1. Fajria L. Pengaruh Pemberian Buah Pepaya Terhadap Nafsu Makan Anak Berumur 2-5 Tahun di Wilayah Kerja Puskesmas Kuranji. NERS J Keperawatan. 2016;9(1):45.

2. Kartiningrum ED. Faktor Risiko Kejadian Gizi Kurang pada Balita di Desa Gayaman Kecamatan Mojoanyar. 2015;7(2):67-80.

3. Ambarwati FR. Ilmu Gizi dan Kesehatan Reproduksi. Yogyakarta: Cakrawala Ilmu; 2015. 138 p.

4. Yisak H, Gobena T, Mesfin F. Prevalence and risk factors for under nutrition among children under five at Haramaya district, Eastern Ethiopia. BMC Pediatr [Internet]. 2015;15(1):1-7. Available from: http://dx.doi.org/10.1186/s12887-015-0535-0

5. Hidayati NL, Prabantini D. Kiat Mengatasi Anak Susah Makan. Yogyakarta: Andi Offset; 2011. $96 \mathrm{p}$.

6. Sudjatmoko. Masalah Makan pada Anak. J Med. 2011;10(1):36-41.

7. Shanti R, Qur N, Nihayati HE. Faktor Yang Berhubungan Dengan Kemampuan Mengatasi Kesulitan Makan Balita Usia 3-5 Tahun Dengan Status Gizi Kurang. 2013;67-78.

8. Sahu SK, Kumar SG, Bhat BV, Premarajan KC, Sarkar S, Roy G, et al. Malnutrition among underfive children in India and strategies for control. J Nat Sci Biol Med. 2015;6(1):18-23.

9. Kurnia R. Fakta Seputar Pepaya. Jakarta: Bhuana Ilmu Popular; 2018. p. 138 pages.

10. Mawaddah N. Pengaruh Pemberian Buah Pepaya Bangkok terhadap Peningkatan Berat Badan Balita Usia 2-5 Tahun Di PAUD ISLAMI TPA MUTHIA DAN TPA BHAKTI ANAK INDONESIA (BAI) Ambarketawang Gamping Sleman Yogyakarta Vol. 53, Journal of Chemical Information and Modeling. 2017.

11. Setiowati W, Wardaniyah L. Pengaruh Pemberian Buah Pepaya Bangkok (CARICA PAPAYA L) TERHADAP Nafsu Makan pada Aanak Usia 3-6 Tahun (The Effect Of Giving Pepaya Bangkok Fruit (Carica Papaya L) On Eating Feeding In Children Ages 3-6 Years) Wiulin. Darul Azhar. 2019;8(1):120-8.

12. Perdani ZP, Hasan R, Nurhasanah N. Hubungan Praktik Pemberian Makan Dengan Status Gizi Anak Usia 3-5 Tahun Di Pos Gizi Desa Tegal Kunir Lor Mauk. J JKFT. 2017;1(2):9.

13. Kesuma A, Novayelinda R, Sabrian F. Faktor-Faktor yang Berhubungan dengan Perilaku Kesulitan Makan Anak Pra Sekolah. JOM. 2015;2(2):1-9.

14. Fauziah L, Rahman N, Hermiyanti. Faktor Risiko Kejadian Gizi Kurang pada Balita Usia 24-59 Bulan Di Kelurahan Taipa Kota Palu. J Ilm Kedokt. 2017;4(3):29-59.

15. Nurmahmudah DK, Aruben R, Suyatno. Faktor-faktor yang Mempengaruhi Konsumsi Makan Buah dan Sayur pada Aanak Pra Sekolah PAUD TK SAPTA PRASETYA KOTA SEMARANG. J Kesehat Masy. 2015;3(1):1689-99. 